\title{
A study of failure and abandonment of public sector-driven civil engineering projects in Nigeria: An empirical review
}

\author{
E.C. Ubani and C.N. Ononuju \\ Department of Project Management Technology \\ Federal University of Technology, Owerri, Nigeria
}

\begin{abstract}
Incessant failure and abandonment of public sector projects are still posing serious concern and challenges to the society and other stakeholders in civil engineering and construction industries. The study identifies and examines the salient factors and the warning signals responsible for failure and abandonment of public sector driven civil engineering projects with a view of directing efforts towards forestalling the problems. Opinion survey was adopted with area and judgmental sampling procedures. Primary data based on the identified factors, was captured with the instrument of questionnaire from professionals in civil engineering projects operating in the South East geopolitical zone of Nigeria. The analytical tools used in the study were severity index, spearman's rank correlation coefficient, relative agreement factors and Kendall's coefficient of concordance (W.). The rankings of different professionals were significantly correlated. The result of percentage relative agreement factors indicates that the most salient factors causing failure and abandonment of public sector driven civil engineering projects in order of significance are frequent changes in government and political power, unreliable mode of financing and payment of completed work, and project contract sum indirectly used to compensate political big-wigs etc. Wtest further substantiates the results by indicating significant degree of concordance in opinion of experts. The study therefore concludes that politically- induced corruption, undefined and non compliance to the agreed mode of financing and payment of completed work are the bane of project success. It is therefore a matter of legislation and policy formulation which should be instituted to avert failure and abandonment of public sector-driven civil engineering projects.
\end{abstract}

Keywords: Public sector project, warning signal, political power, project monitoring and evaluation, system approach, cost and social benefits.

\section{INTRODUCTION}

Failure and abandonment of public sector driven civil engineering projects, though rampant in Nigeria, are not restricted to developing countries alone. However, they are recurrent and well known concepts of civil engineering projects in Nigeria. In Nigeria today, the landscape is littered with abandoned buildings, roads, rails, ports and other infrastructural projects at all levels of governance, from local government through the state government to the federal level. Engineering project is described as a scheme or an undertaking designed to achieve specific objectives of the promoters or clients. Civil engineering projects which include construction, operations and maintenance of facilities are demanding and require massive investment whose returns come very slowly with possible leakage of cash flow management. Unfortunately, many of these projects in Nigeria are out rightly abandoned even at the conception stage hence, the need to review the contemporary issues on the subject matter.
Considering the low level of completion of many civil engineering projects executed in Nigeria from 1999 to 2012, and the level of devastation inflicted to various parties in the project execution process, it becomes imperative to critically examine the warning signals and causes of project failure and abandonment and propose appropriate measures that would help to reduce the occurrence. Hence, there is urgent need to look inward and examine salient factors militating against the success objectives of the civil engineering project, in accordance with its charter. Therefore, this study discusses and explores the warning signals and factors that lead to failure and abandonment of public sector civil engineering projects through the following specific objectives.

* To identify the causes of failure and abandonment of civil engineering project.

* To explore the failure mode criteria and warning signals so as to predict impending 
failure and abandonment of civil engineering projects through subjective reasoning.

* To discuss and study the contributory factors to success and failure in the implementation of civil engineering projects by government consultants and professionals.

* To suggest workable solutions to forestall the future problems of failure and abandonment of civil engineering projects.

The study is significant because; prevention is better than remedial actions. Also elimination or reduction of failure rate and significant increase in the successful level of civil engineering projects will result to provision of good roads, housing, bridges, dams, railways and other infrastructures for benefit of the populace. It will create employment opportunities for teaming youths and professionals in the field of civil engineering. There will be reduction in waste of fund, human and materials on the part of the clients, as well as enhanced physical and socio-economic development of the country amongst others. The following research question is necessary. What are the warning signals to failure and abandonment of civil engineering project?

There could be several ways to describe project failure and abandonment. Project failure could be defined as project which did not meet up with scope, time, quality and cost goals. The project could not satisfy the customer/sponsor, and the results of the project fails to meet its main objectives, such as making or saving a certain amounts of money, providing a good return on investment or simply, making the sponsor happy. When a project fails without concerted efforts for resuscitation, project abandonment is therefore inevitable. Olalusi and Otunola (2012), cited a case with building projects and posit that abandonment can be an owner ceasing to provide maintenance and operating services to a building, or the loss of an owner's right to a building, or the demolition of a building. An abandoned civil engineering project is not usually completed in a time frame of the contract. Therefore, project failure is the failure to achieve the salient criteria of project management vis-à-vis scheduled completion within budget, satisfactory technical performance and, client and customers acceptance. Nwachukwu et al, (2010) describe project abandonment as the refusal or failure, to complete a contract before a practical completion dates.
From ethical perspective, project managers play a vital role in helping projects succeed. Project managers work with the project sponsors, the project team, and other people involved in a project to meet project goals. Odusami and Ameh (2002) postulate that the project managers principal responsibilities are to deliver the project's end-item within budget and time limitations in accordance with technical specifications and when specified, in fulfillment of project objectives. They also work with sponsor to define success criteria for a particular project. Schwalble (2006) asserts that, good project managers do not assume that their definition of success is the same as that of the sponsor. The private sector operators work more from the angle of financial profit maximization, while the public sector thinks in terms of social costs and benefits (Okorafor 2004). In Nigeria, cost and time overruns are given as the most important factors for project abandonment or contractors failure (Elinwa and Joshua 2001); and they are more rampant in the public sector projects. Failure and abandonment of civil engineering projects in public sector have resulted to colossal waste of scarce resources, environmental degradation, unemployment, aggravated deterioration and decay of road and infrastructure, ravaging flood, displacement of homes, destruction of buildings and other settlements etc.

Project failure and abandonment can therefore be described as resultant effects of the projects that have started at an earlier date, but which the construction work for one reason or the other has stopped. These are not limited to buildings alone, but to other civil engineering projects such as roads, industrial structure, bridges, factories, dams, electricity, communication projects etc. Chitkara (2006) asserts that it is not uncommon to see a project failing to achieve its mission of creating a facility within the specified cost and time. Hardly, few projects get completed in time and within the original costs. Chitkara (2006) further cited the case of annual year 1989 - 90 report of ministry of programme implementation of India. According to him, out of 351 projects each costing over Rs 20 crore, $56 \%$ had cost overrun (totally $20 \%$ cost), 49 faced a time overrun from 1 to 157 months.

The factors contributing to these overruns are outlined and discussed as follow:

- $\quad$ Inadequate project formulation; Poor field investigation, inadequate project information, bad cost estimates, lack of experience, 
inadequate project analyses, poor investment decisions.

- Poor planning for implementation: Inadequate time plan, inadequate resource plan, inadequate equipment supply plan, inter-linking not anticipated, poor organization, poor cost planning.

- Lack of proper contract planning and management: Improper pre-contract actions, poor post award contract management.

- Lack of project management during execution: Inefficient and ineffective work schedule, delays, changes in scope of work and location law.

There can be other endless reasons for nonfulfillment of project objectives. Failures can be due to unforeseen natural calamities like earthquakes, floods and natural disasters. Failures can also result from deliberate attempts made by manipulators during the feasibility stage by incorporating inaccurate time and cost estimates with a view to secure business or start a project. These in-built intentional inaccuracies can lead to unrealistic objectives and thus create problems during the implementation stage. But, the main causes of such failure can be attributed to the cost estimation failure and management failure.

Characteristics of civil engineering projects: Civil engineering, construction, petrochemical, mining and quarrying projects, which have in common, the fact that the fulfillment phase must be conducted on a site are exposed to the elements of risk and remote from the contractors head office. Lock (1997) asserts that these projects incur special risks, and problems of organization and communication. They often require massive capital investment, and they deserve (but do not always get) rigorous management of progress, finance and quality. If concerted and efficient management processes with highly skilled manpower are not put in place, the resources, time and work progress may not be properly managed thus leading to time and cost overruns with shoddy output, hence failure and abandonment of the projects. Also, the amount of finance and other resources in such projects may be too great for one contractor to invest, in which case, the organization and communication are further complicated by the participation of several contractors, working in a some kind of joint venture.

Okorafor (2004) state that funding of many civil engineering projects and road network development had always fallen within the realm of the public sector activities because of the perceived social benefits. Roberts (2009) posits that the primary goal of someone who runs a department of administrators in the public sector is to ensure that staff execute the defined processes properly. But in contrast, an entrepreneur starts with a blank convas, his goals reached through vision, drive and unilateral decisions, being to create something new and profitable. Roberts (2009) further argues that public sector managers are not bred to change things by being innovative and decisive. They are bred to ensure that the existing process are properly administered, which clearly leaves the public sector at something of a disadvantage when it comes to projects.

Theoretical framework : In project management, the organization can be thought of as a system composed of subsystem such as finance, operation/implementation, planning, control, procurement and purchasing subsystems etc. According to Stevensons (2007), a system viewpoint is almost always beneficial in decision making. Kerzner (2004) defines system approach as a logical and discipline process of problem solving. The system approach forces review of interrelationship of various subsystems. It is a dynamic process that integrates all activities into a meaningful total system, systematically assembles and matches the parts of the system into a unified whole, and seek an optimal solution or strategy in solving a problem. The study therefore attempts to explore and consider system approach to solving the problems of project failure and abandonment in the public sector as failure of some subsystems could serve as a warning signal to the entire project. Kerzner (2004), identifies phases of development of system approach to problem solving as translation and definition of problem, determination of objectives cum criteria, analysis, trade-off analysis and synthesis. Telsang (2004) states that there are many specific causes of failure of components and system, which may include; deficiencies in design, improper selection of process and manufacturing techniques, lack of knowledge and experience, errors of assembly, improper service conditions, inadequate maintenance, variation in environmental and operating conditions, and human errors. In analogous with projects, an item may fail in may ways, and different failure modes as cited from Telsang (2004) are; catastrophic, degradation/creeping, independent, secondary failure and failure due to improper handling and misuse. Chandara (2006) examines failures in projects from 
the angle of present value of expected cash flow and capital expenditure management. Capital expenditure management is a dynamic process and capital investment cannot be regarded as a commitment till the end of the project life. As time rolls on, changes occur which can alter the attractiveness of projects or even the entire investment. Hence, capital investments must be reappraised periodically to determine whether they should be continued or terminated or divested. To decide whether the project should be continued or terminated, or divested, the following information is required.

Present value of expected cash flow (PVCF) is defined as

$\mathrm{PVCF}=\sum_{n=1}^{m} \frac{N C_{n}}{(1+r)^{n}}$

where $m$ is the balance life of the project at the time of review and $r$ is the appropriate discount rate.

$\mathrm{C}_{\mathrm{t}}=$ Forecast of cash flow for period $\mathrm{t},(\mathrm{t}=0$, $1 \ldots \ldots \ldots \ldots \ldots \ldots \ldots . n)$

$\mathrm{NC}_{\mathrm{t}}=$ New forecast of cash flow in period $\mathrm{n}$ assessed at the end of year the project is reviewed.

$A_{t}=$ Actual cash flow in period $t(t=0,1 \ldots \ldots$ end of year of review).

Salvage value (SV): This is the value expected to be realized from terminating the project and selling its assets.

Divestiture value (DV): This is the price offered by a third party to buy the project.

Given the value of PVCF, SV and DV, the following are the decision rules.

IF

$$
\begin{gathered}
\mathrm{PVCF}<\mathrm{SV}<\mathrm{DV} \\
\text { Divest } \\
\mathrm{PVCF}<\mathrm{DV}<\mathrm{SV} \\
\text { Terminate } \\
\mathrm{SV}<\mathrm{DV}<\mathrm{PVCF} \\
\text { Continue } \\
\mathrm{SV}<\mathrm{PVCF}<\mathrm{DV} \\
\text { Divest } \\
\mathrm{DV}<\mathrm{SV}<\mathrm{PVCF} \\
\text { Continue } \\
\mathrm{DV}<\mathrm{PVCF}<\mathrm{SV} \\
\text { Terminate }
\end{gathered}
$$

This rule says that the project must be abandoned if the net present value associated with abandonment is greater than the net present value associated with continuation and vice versa.

\section{METHODOLOGY}

An empirical and opinion survey method with area and judgmental sampling techniques were used in the study. The primary data used for the study was obtained from architects, quantity surveyors, civil engineers/builders and project managers/government agencies involved in the monitoring and evaluation of public sector civil engineering projects in South East geopolitical zone of Nigeria. The methods used in the collection of data and other relevant information are literature search, oral interview and questionnaire administered to the experts professionals who have participated in some failed and abandoned civil engineering projects such as Onitsha Enugu, and Enugu-Port Harcourt express roads, flyover projects in Owerri, Imo State etc. The statistical methods used in the analysis of data are severity index (S1), spearman's rank correlation coefficient $\rho$, relative agreement factor RAF and Kendalls coefficient of concordance W.

Table 1: Distribution and responses on questionnaires among the professionals in the Eastern states of Nigeria on causes of Failure and Abandonment of Public Sector Projects.

\begin{tabular}{|l|c|c|c|c|}
\hline State & Number Distributed & $\begin{array}{c}\text { Number of } \\
\text { Responses }\end{array}$ & $\begin{array}{c}\text { Number Distributed } \\
(\%)\end{array}$ & $\begin{array}{c}\text { Total Number of } \\
\text { Responses (\%) }\end{array}$ \\
\hline Imo & 20 & 17 & 17 & 23.61 \\
Anambra & 20 & 15 & 15 & 20.83 \\
Abia & 20 & 12 & 12 & 16.67 \\
Enugu & 20 & 16 & 16 & 22.22 \\
Ebonyi & 20 & 12 & 12 & 16.67 \\
\hline Total & 100 & 72 & 72 & 100.00 \\
\hline
\end{tabular}


Severity index (SI) was used to determine the severity and ranking of each identified factors responsible for failure and abandonment of public sector civil engineering projects in Nigeria. The Spearman's Rank Correlation Coefficient $\rho$ was used to determine the strength or degree of agreement of the identified factors among pairs of expert professionals also known as respondents. The Relative Agreement Factor (RAF) was used in the determination of the significant ranking on the opinions and subjective assessments of all the 4 respective professionals on the 23 identified factors responsible for failure and abandonment of public sector civil engineering projects. The mathematical expressions for $\mathrm{SI}, \rho$ and RAF are presented as:

$S I=\left(\frac{\sum_{i=0}^{4} a_{i} x_{i}}{4 \sum_{i=0}^{4} x_{i}}\right) \times 100 \%$.

where $\alpha=$ constant expressing weight given to $\mathrm{SI}, \mathrm{x}_{\mathrm{i}}$ $=$ variable expressing the frequency of the response for $\mathrm{SI}=0,1,2,3$ or 4 and is illustrated as follows:

$\mathrm{x}_{0}=$ frequency of strongly disagree (SD), $\mathrm{x}_{1}=$ frequency of disagree (DA), $\quad x_{2}=$ frequency of neutral $(N T), x_{3}=$ frequency of agree (AG), $x_{4}=$ frequency of strongly agree (SA), where SD, DA, NT, $A G$ and SA represent; not applicable factor, poor factor, average factor, good factor, very good factor respectively. Spearman rank correlation coefficient $\rho$ was used to measure the degree of correlation between paired professionals in ranking of the factors that measure project failure and abandonment.

$$
\rho=1-\frac{6 \Sigma d^{2}}{n\left(n^{2}-1\right)} .
$$

where $d=$ difference in rank between two professions, $n$ $=$ number of cases

Also, the Relative Agreement Factor (RAF) and the Percentage RAF (PRAF) are calculated using Elinwa and Joshua (2001).

$$
R A F=\frac{\Sigma A E Q M}{n} .
$$

where: $\mathrm{A}=$ architects, $\mathrm{E}=$ civil engineers, $\mathrm{Q}=$ quantity surveyors,

$M=$ project managers/Govt agencies involved in monitoring and evaluation.
$P R A F=\frac{R A F_{\text {max }}-R A F_{i}}{R A F_{\text {max }}}$.

where $\mathrm{RAF}_{\max }=$ maximum $\mathrm{RAF}$

$\Sigma A E Q M=$ sum of order of rankings by architects, engineers, quantity surveyors and project managers/government agencies involved in monitoring and evaluation of projects.

An absolute difference in rank of 2 for example, implies that the group agreed more than when the absolute difference in rank is 3 . The rank agreement factor can be $>1$, with a higher factor implying greater disagreement.

Kendall's coefficient of concordance W, an important non parametric measure of relationship was used to determine the degree of association among the four sets of ranking of the twenty three identified factors responsible for failure and abandonment of public sector civil engineering projects as posited by professionals. Mathematically, $\mathrm{W}$ is expressed as

$W=\frac{S}{\frac{1}{2} K^{2}\left(N^{3}-N\right)}$ where $S=\Sigma\left(R j-\bar{R}_{j}\right)^{2} \cdot$.

$\mathrm{n}=$ number of set of rank ie number of judges

$\mathrm{N}=$ number of objects ranked. However computer based W-test was adopted using statistical Program for Social Sciences (SPSS) version 15.

Table 2: Hypothetical factors responsible for failure and abandonment of public sector civil engineering projects and

\begin{tabular}{|c|c|}
\hline (Code) & Factor \\
\hline $\mathrm{X}_{1}:$ & $\begin{array}{l}\text { Lack of available skilled personnel and } \\
\text { technical experts }\end{array}$ \\
\hline $\mathrm{X}_{2}:$ & $\begin{array}{l}\text { Ineffective project planning, and control } \\
\text { including underestimation of time and cost }\end{array}$ \\
\hline $\mathrm{X}_{3}:$ & Poor risk management \\
\hline $\mathrm{X}_{4}:$ & $\begin{array}{l}\text { Misunderstanding of the work requirement and } \\
\text { non compliance with condition of contract. }\end{array}$ \\
\hline $\mathrm{X}_{5}:$ & $\begin{array}{l}\text { Poor monitoring and quality control by } \\
\text { regulatory agencies }\end{array}$ \\
\hline $\mathrm{X}_{6}$ : & $\begin{array}{l}\text { Corruption and communication gap among } \\
\text { project personnel }\end{array}$ \\
\hline $\mathrm{X}_{7}:$ & $\begin{array}{l}\text { Designers and contractors inability to do the } \\
\text { work }\end{array}$ \\
\hline $\mathrm{X}_{8}:$ & $\begin{array}{l}\text { Failure on the part of contractors to obtain vital } \\
\text { inputs such as materials, manpower and } \\
\text { machines. }\end{array}$ \\
\hline
\end{tabular}
their respective code. 


\begin{tabular}{|l|l|}
\hline $\mathrm{X}_{9}:$ & $\begin{array}{l}\text { Frequent changes is government and political } \\
\text { power }\end{array}$ \\
\hline $\mathrm{X}_{10}:$ & $\begin{array}{l}\text { Vulnerability to and ravaging environmental } \\
\text { degradation and devastation due to wrong } \\
\text { location. }\end{array}$ \\
\hline $\mathrm{X}_{11}:$ & $\begin{array}{l}\text { Youth restiveness, and land ownership } \\
\text { disputes }\end{array}$ \\
\hline $\mathrm{X}_{12}:$ & $\begin{array}{l}\text { Mode of financing and payment for completed } \\
\text { work }\end{array}$ \\
\hline $\mathrm{X}_{13}:$ & $\begin{array}{l}\text { Scarcity and lack of original materials } \\
\text { requirement }\end{array}$ \\
\hline $\mathrm{X}_{14}:$ & $\begin{array}{l}\text { Capacity constraints in terms of construction } \\
\text { equipments }\end{array}$ \\
\hline $\mathrm{X}_{15}:$ & $\begin{array}{l}\text { Frequent changes and inconsistence in } \\
\text { government policy and priority }\end{array}$ \\
\hline $\mathrm{X}_{16}:$ & $\begin{array}{l}\text { Litigations and court injunctions } \\
\text { Project scope creep with massive amount of } \\
\text { change or variation orders }\end{array}$ \\
\hline $\mathrm{X}_{17}:$ & $\begin{array}{l}\text { Project contract sum indirectly used to } \\
\text { compensate political party big-wigs }\end{array}$ \\
\hline
\end{tabular}

\begin{tabular}{|l|l|}
\hline $\mathrm{X}_{19}:$ & $\begin{array}{l}\text { Colossal waste of resources in project } \\
\text { implementation due to unacceptable design } \\
\text { errors and mistakes }\end{array}$ \\
\hline $\mathrm{X}_{20}:$ & Force majeure and terrorism \\
\hline $\mathrm{X}_{21}:$ & Militancy and criminal hideouts \\
\hline $\mathrm{X}_{22}:$ & $\begin{array}{l}\text { Inaccessibility and geo hazardous impassable } \\
\text { terrain to the project site }\end{array}$ \\
\hline $\mathrm{X}_{23}:$ & $\begin{array}{l}\text { Prequalification procedure and corrupt } \\
\text { government officials. }\end{array}$ \\
\hline
\end{tabular}

Source: Empirical and literature survey.

Also, the weighted score of the factors of project failure and abandonment from the professionals were captured based on the following metrics for level of agreement and disagreement: $S A=$ strongly agree. $\mathrm{AG}=$ agree, $\mathrm{NT}=$ neutral $\mathrm{DA}=$ disagree, $\mathrm{SD}=$ strongly disagree.SI was used to obtain the value of percentage index and ranking of the factors based on calculated percentage index from the four categories of professionals respectively.

Table 3: $\quad$ Summary of classification of weighted score of factors responsible for project failure and abandonment by professionals in Eastern Nigeria.

\begin{tabular}{|l|c|c|c|c|c|c|}
\cline { 2 - 7 } \multicolumn{1}{c|}{} & \multicolumn{9}{c|}{ Classification of factors } \\
\hline Professionals & SA & AG & NT & DA & SD & Total \\
\hline Architects (A) & 4 & 10 & 8 & 1 & 0 & 23 \\
\hline Quantity surveyors (Q) & 3 & 7 & 10 & 3 & 0 & 23 \\
\hline Civil Engineers (E) & 5 & 12 & 6 & 0 & 0 & 23 \\
\hline Project managers/Govt. agencies (M) & 4 & 12 & 7 & 0 & 0 & 23 \\
\hline
\end{tabular}

$\mathrm{SA}=80 \leq \mathrm{I} \leq 100, \mathrm{AG}=60 \leq \mathrm{I} \leq 80, \mathrm{NT}=40 \leq \mathrm{I} \leq 60, \mathrm{DA}=20 \leq \mathrm{I} \leq 40, \mathrm{SD}=0 \leq \mathrm{I} \leq 20$

where $\mathrm{I}=$ mean severity index.

The ranking of the factors from each professionals, the mean rank for $W$ test, computation of $\Sigma A Q E M$, RAF and PRAF and their respectively ranking are shown in the summary of combined agreement of all the professionals.

\section{RESULTS AND DISCUSSION}

The Spearman's Rank Correlation Coefficients (from the equation) for factors responsible for failure and abandonment of public sector civil engineering projects in Nigeria among each pair of professionals are as follow; architects/civil engineers $=0.75$, architects/project monitors and evaluators $=0.83$, quantity surveyors/civil engineers $=0.74$, quantity surveyors/project monitors and evaluators $=0.79$, civil engineers/project monitors and evaluators = 0.69 . The result of $W$-test indicates significant relationship and agreement among the four professionals on the causes of failure and abandonment of public sector civil engineering projects.

The empirical reports from the field survey indicates that the pointers to the mode and warning signals for project failure and abandonment in the public sector civil engineering projects are as follow.

When there are changes in the government policies and political powers especially from one political party to another, inconsistency in the agreed terms of payment, scope creep, inflation in the prices of civil engineering materials and equipment, and ineffective project design, design errors and myopic technical feasibility studies requiring frequent scope changes, modification and correction beyond the capacity of the professionals in the field. The study also indicates that the failure and abandonment of public sector civil engineering project will crop up if the warning signals and modes are not remedied on time. 
Am. J. Sci. Ind. Res., 2013, 4(1): 75-82

Table 4: Individual and combined agreement of professional ranking based on PRAF and mean ranks (for w-test) on the causes and warning signal for failure and abandonment of public sector civil engineering projects.

\begin{tabular}{|l|l|l|l|l|l|l|l|l|l|c|}
\hline $\begin{array}{l}\text { Variables } \\
\text { and their } \\
\text { constructs }\end{array}$ & $\begin{array}{l}\text { Architect } \\
\text { ranking }\end{array}$ & $\begin{array}{l}\text { Quantity } \\
\text { surveyor } \\
\text { ranking }\end{array}$ & $\begin{array}{l}\text { Civil } \\
\text { Engineers } \\
\text { ranking }\end{array}$ & $\begin{array}{l}\text { Project } \\
\text { monitors/ } \\
\text { Evaluators } \\
\text { ranking }\end{array}$ & $\begin{array}{l}\text { Sum of } \\
\text { ranking } \\
\sum \text { MAEE } \\
M\end{array}$ & RAF & PRAF & $\begin{array}{l}\text { Ranking } \\
\text { order } \\
\text { based on } \\
\text { PRAF }\end{array}$ & Mean rank for W-test \\
\hline$X_{9}$ & 1 & 1 & 2 & 1 & 5 & 0.22 & 94.05 & 1 & 1.25 & 23rd \\
\hline$X_{12}$ & 5 & 2 & 3 & 4 & 14 & 0.61 & 83.51 & 2 & 15.50 & 22 nd \\
\hline$X_{18}$ & 7 & 3 & 5 & 2 & 18 & 0.78 & 78.92 & 3 & 4.25 & 21 st \\
\hline$X_{10}$ & 6 & 4 & 4 & 6 & 20 & 0.87 & 76.49 & 4 & 4.88 & 20 th \\
\hline$X_{13}$ & 2 & 14 & 1 & 7 & 24 & 1.04 & 71.89 & 5 & 6.00 & 19 th \\
\hline$X_{11}$ & 3 & 5 & 8 & 10 & 26 & 1.13 & 69.46 & 6 & 6.50 & 18 th \\
\hline$X_{19}$ & 4 & 7 & 13 & 3 & 27 & 1.17 & 68.38 & 7 & 7.00 & 17 th \\
\hline$X_{3}$ & 10 & 6 & 9 & 6 & 31 & 1.35 & 63.51 & 8 & 8.00 & 16 th \\
\hline$X_{15}$ & 13 & 8 & 7 & 9 & 37 & 1.61 & 56.49 & 9 & 9.50 & 14 th \\
\hline$X_{6}$ & 8 & 10 & 6 & 14 & 38 & 1.65 & 55.41 & 10 & 9.50 & 14 th \\
\hline$X_{2}$ & 11 & 13 & 10 & 16 & 40 & 1.74 & 52.97 & 11 & 13.13 & 12 th \\
\hline$X_{8}$ & 9 & 15 & 14 & 11 & 49 & 2.13 & 42.43 & 12 & 12.88 & 13 th \\
\hline$X_{16}$ & 9 & 15 & 20 & 8 & 52 & 2.26 & 38.92 & 13 & 13.75 & 11 th \\
\hline$X_{4}$ & 19 & 11 & 12 & 17 & 56 & 2.43 & 34.32 & 14 & 14.50 & 10 th \\
\hline$X_{5}$ & 14 & 21 & 11 & 12 & 58 & 2.52 & 31.89 & 15 & 15.50 & 9 th \\
\hline$X_{7}$ & 18 & 12 & 18 & 12 & 60 & 2.61 & 29.46 & 16 & 15.63 & 8 th \\
\hline$X_{17}$ & 17 & 18 & 9 & 18 & 62 & 2.70 & 27.03 & 17 & 16.38 & 7 th \\
\hline$X_{14}$ & 12 & 17 & 16 & 19 & 64 & 2.78 & 24.86 & 18 & 17.38 & 5 th \\
\hline$X_{23}$ & 19 & 19 & 14 & 1 & 65 & 2.83 & 23.51 & 19 & 17.38 & 5 th \\
\hline$X_{1}$ & 14 & 20 & 19 & 15 & 68 & 2.96 & 20.00 & 20 & 18.38 & 3 rd \\
\hline$X_{21}$ & 20 & 1 & 15 & 21 & 69 & 3.00 & 18.92 & 21 & 18.83 & 3 rd \\
\hline$X_{22}$ & 21 & 16 & 17 & 19 & 73 & 3.17 & 14.32 & 22 & 19.63 & 2 nd \\
\hline$X_{20}$ & 22 & 22 & 21 & 20 & 85 & 3.70 & 0.00 & 23 & 22.75 & 1 st \\
\hline
\end{tabular}

Table 5: W-Test Result

\begin{tabular}{|l|l|}
\hline \multicolumn{2}{|c|}{ Test Statistics } \\
\hline $\mathrm{N}$ & .4 \\
\hline Kendall's W & .779 \\
\hline Chi-Square & 68.514 \\
\hline $\mathrm{df}$ & .22 \\
\hline Asymp. Sig. & .000 \\
\hline $\begin{array}{l}\text { a. Kendall's Coefficient of } \\
\text { Concordance }\end{array}$ \\
\hline
\end{tabular}

The most salient factors as explored and indicated by the study are; frequent changes in government and political power; misappropriation of fund, mode of financing and payment for completed work, approved project contract sum indirectly used to compensate the big-wigs in the ruling political party. After changes in government, many on-going public sector civil engineering projects of previous governments are flagrantly abandoned or neglected without considering the importance's of such project to national development. The contracts for the project are either terminated or relocated to a preferred site irrespective of amount of fund sunk on the project at its original site. Construction of civil engineering public sector projects involving huge capital outlay are prone to being forced to remain in the shelf for long or completely abandoned if there is no cash in sight for continuity of the projects. The Government agencies through her numerous inconsistent policies, poor consultancy services, funding of projects, and selection procedures are not always proactive for the success of public sector project. The finance are used to only start up the projects and settle political financiers rather than executing the projects. Also, ineffective; project planning, design, technical feasibility studies and poor monitoring and control of project progress during implementation phase are instrumental to the failure and abandonment of many public sector civil engineering projects.

Based on the findings, the following remedies could help to ameliorate the incessant cases of failure and abandonment of public sector civil engineering projects. Appropriate legislation for the continuity of on-going civil engineering projects at the original site irrespective of who is concerned when power changes hand from one political party or person to another. Honouring of payment certificates as and when due so as to enhance contractors cash flow 
Am. J. Sci. Ind. Res., 2013, 4(1): 75-82

and ensure regular progress of the work with little or no delay. This is in concordance will Chandara (2006) that states that capital investment must be reappraised periodically to determine whether the project should be continued, or terminated or divested. Provision of adequate fund by the client based on the proper feasibility studies and capacity assessment for the execution of the project will help to ameliorate the problems. These include the determination and evaluation of manpower, technical and professional capacities prior of project implementation.

Public sector civil engineering projects are the hub of and necessary requirements for social, economic and industrial development in Nigeria. The incessant failure and abandonment are serious challenges constraining the realization of national policy objectives in these sectors. The study has holistically identified and examined the contemporary issues and causative factors of failure and abandonment of civil engineering projects by using survey technique of research design, area and random sampling procedure. The data was captured by questionnaire, SI determined the severity of each factors and ranked them among professional, $\rho$ assesses the degree of closeness of opinion in ranking of each factor among the pairs of professional and RAF ranked the collective opinions of all the factors among all the professionals involved in the development of public sector civil engineering projects in Nigeria. Also, W tested the degree of agreement on the subject matter by all the professionals. Many salient factors accounted for these problems ranging from frequent changes in government and political power, corruption and mode of financing, the use of political undertone rather than economic advantage in sitting of projects, sharing of contract sum meant for development by the contractors and political interest group in power, ineffective project planning, poor feasibility studies and design, lack of technological capacity as well as inability to detect failure warning signals on time. Recommendations and suggestions are proffered for appropriate legislation for continuity of public sector civil engineering projects irrespective of government in power, decisiveness in the containment of corruptions for contract administration by government anti graft agencies and institution of policy for honouring the mode of financing and payment for completed work of the projects as contained in the contract documents.

\section{REFERENCES}

Chandara P. (2006) Project Planning, Selection, Financing, Implementation and Review. Sixth Edition. Tata McGraw Hill. http://highered.Mcgraw-hill.com: 80 sites/0070617295

Chitkara K.K. (1998) Construction Project Management: Planning, Scheduling and Controlling. Tata McGrawHill Publishing Compay. New Delhi.

Elinwa A.U. and Joshua M. (2001) Time-Overrun Factors in Nigeria Construction Industry. Journal of Construction Engineering and Management. Vol. 127, No. 5.

Kerzner H. (2004) Project Management; A System Approach to Planning, Scheduling and Controlling. Second Edition CBS Publishers and Distributors.

Lock D. (1997) The Essentials of Project Management. Published by Gower Publishing Limited.

Nwachukwu C.C. Echeme I and Okoli M.N. (2010) Project Management Factor Indexes: a Constraint to Project Implementation Success in the Construction Sector of a Developing Economy. European Journal of Scientific Research Vol. 43, No. http://www.eurojournals.com/ejsr.htm.

Odusami K.T. and Ameh O.J. (2002). Nigerian Construction Project Managers Educational Level and need in Project Management. Department of Building, University of Lagos E-mail: cronini2002@yahoo.com.

Okorafor G.F. (2004) Impact Analysis of Federal Highways on the Local Economy. A case of selected highways in Nigeria Unpublished PhD Thesis, Federal University of Technology Owerri - Nigeria.

Olalusi O. and Otunola A. (2012) Abandonment of Building Projects in Nigeria- Review of Causes and Solutions International Conference on Chemical, Civil and Environment Engineering (C.C.E.E) Dubai.

Roberts M.H. (2009) Project Management in the Public ector. http://www.hraconsulting-ltd.co.uk/projectmanagement-in-the- ublic sector.htm.

Schwable K. (2006) Introduction to Project Management. Thomson Course

Technology.www.thomsonrights.com.

Stevenson W.J. (2007) Operations Management: Nineth Edition McGraw-hill Irwin.www.mhhe.com.

Telsang M. (2004) Industrial Engineering and Production Management. S. Chand and Company Ltd. New Delhi. 